\title{
Tourism Enterprises' Willingness to Contribute to Payment for Ecosystem Services (PES) Program in Gili Matra, Indonesia
}

\author{
D Diswandi* \\ Faculty of Economics and Business \\ University of Mataram \\ Mataram, Indonesia \\ diswandi@unram.ac.id \\ Luluk Fadliyanti \\ Faculty of Economics and Business \\ University of Mataram \\ Mataram, Indonesia \\ fadliyanti@unram.ac.id
}

\author{
Mansur Afifi \\ Faculty of Economics and Business \\ University of Mataram \\ Mataram, Indonesia \\ mansurafifi@yahoo.de \\ $\mathrm{H}$ Hailuddin \\ Faculty of Economics and Business \\ University of Mataram \\ Mataram, Indonesia \\ feryanlin@yahoo.co.id
}

\begin{abstract}
Tourism activities generally put more emphasis on the provision of maximum economic benefit. Less attention is given to its environmental impact and this can lead to disruption in the condition of the physical environment. If this continues, then, in the long run, the physical environment in the region will be no longer attractive and be harmful to the tourism sector. To achieve sustainable tourism, harmonization of tourism and conservation activities would be essential. One potential effort to be implemented is through the Payment for Ecosystem Services (PES) program. By taking a case study of marine tourism in the Gili Matra in West Nusa Tenggara Province, this study analyses the potential for achieving sustainable tourism through harmonizing marine tourism activities and conservation of coral reefs and other marine biotas, through the PES scheme. Using the contingent valuation method (CVM), this study seeks tourism entrepreneurs' willingness to contribute to funding the PES program. The study found that tourism entrepreneurs are willing to pay an average of $R p \quad 42,200$ (equal to 2.86 USD) per month for the PES fund. The level of revenue, length of business, and impact of coral on the respondent's economy influence the willingness and the amount to pay.
\end{abstract}

Keywords-Payment for Ecosystem Services, Sustainable Tourism, Contingent Valuation Method

\section{INTRODUCTION}

Maritime tourism has become a priority of Indonesia's tourism industry[1]-[4]. Gili Matra, located in the North Lombok district of West Nusa Tenggara, is one of the fastgrowing maritime tourism destinations in Eastern Indonesia. The main tourist attraction in Gili Matra is the beauty of the marine park, including the coral reefs.

The coral reef is an ecosystem service-the beneficial ecological elements that the society enjoys directly or indirectly from the ecosystem or environmental security [5][8]. The presence of coral reefs as an environmental service in Gili Matra is very dependent on the conservation efforts of the related parties. The activities of tourists and fishermen have harmed the sustainability of coral reefs in the region [9]. Efforts are therefore required to harmonize tourism and conservation activities. In this situation, Gili Matra's tourism activities need to be coordinated with conservation initiatives, including the conservation of coral reefs.

Payment for Ecosystem Services (PES) is one of the possible attempts to conserve coral reefs. PES is characterized as a voluntary transaction in which at least one environmental service purchaser purchases a specified environmental service from at least one environmental service provider on the condition that the provider continues to maintain the associated resource to ensure the sustainability of the environmental service [10], [11]. This model is explicitly designed to provide benefits by offering financial incentives for those who control natural resources.

Several studies have been conducted in different countries on the contribution of PES initiatives to sustainable natural resource management and community empowerment. For example, Bremer et al. [12] found that the PES program in Ecuador has made a positive contribution to community empowerment and sustainable natural resource management. Research conducted by Allendorf et al. in China shows that understanding ecosystem services can be the basis for harmonizing the relationship between people's economic livelihoods and environmental protection [13]. However, this study emphasizes knowledge and does not formulate a form of action designed to harmonize economic and conservation practices. Schuhmann et al. studied the ability of divers (Scuba divers) to pay for marine biodiversity in Barbados, the Caribbean island [14]. They found that there is a potential for increased conservation of marine biota through the economic benefits of diving tourism in the region. However, the report has not yet proposed a scheme to align tourism activities with the protection of coral reefs and marine life.

Considering the existence of the research gap, this study would explore the potential for sustainable harmonization of marine tourism and marine conservation practices (including coral reefs conservation) under the PES schemes. 


\section{METHOD}

The study uses a mixture of quantitative and qualitative methods. Primary data were collected by surveys and direct observation. In the meantime, secondary data were collected through a scientific report provided by the government stakeholders. The Willingness to Pay (WTP) survey was conducted to capture the willingness of entrepreneurs to pay a certain amount of cash for the existence of coral reefs and marine biota. The population of this study consisted of 445 tourism entrepreneurs in Gili Matra. A sample of 82 entrepreneurs was randomly chosen using the Yamane formula [15],[16].

The WTP survey was performed using the Contingent Valuation Method (CVM). This is to address research questions related to the willingness and capacity of entrepreneurs to pay for the presence of ecosystem resources that are tourism artifacts. In addition, a study of the factors influencing the WTP of the entrepreneur was also carried out in the WTP analysis using multiple regression analysis. The willingness of the respondent to pay is presumed to be influenced by several independent variables defined by vector $\mathrm{x}$ and formulated as the following:

$$
\mathrm{WTPi}^{*}=\beta 0+\beta \mathrm{xi}+\varepsilon \mathrm{I}
$$

where $B$ is the vector of the slope parameter, and $x i$ is the vector of the observations of the person $i$ in the explanatory variable. An error term $(\varepsilon)$ is considered to be a random variable usually distributed with a zero mean value. The independent variables used in this model are the level of education, type of business ownership, turnover, length of business, level of environmental awareness, and the effect of coral reefs on the respondent's life. Regression with the Ordinary Least Square (OLS) method will be performed to evaluate this model.

\section{RESULT AND DISCUSSION}

\section{A. Willingness to pay (WTP) of tourism entrepreneurs for the existence of coral reefs}

The willingness to pay (WTP) for the existence of a natural resource is defined as a proxy of someone's willingness to pay for environmental services at the related natural resource. In the context of this study, the WTP for the presence of coral reefs is an indication of the WTP for the environmental services produced by the coral reefs. The amount of WTP can also mean someone's willingness to fund coral reef conservation.

The survey results using the Contingent Valuation Method (CVM) indicate that the average WTP of tourism entrepreneurs for the PES fund in Gili Matra is Rp 42,200 (equal to 2.99 USD) per month. The lowest WTP is zero rupiahs, which means that there are entrepreneurs who do not want to pay for coral reef conservation or other environmental services. Meanwhile, the highest WTP was Rp 500,000 (equal to 35.39 USD) per month. Of the ninetynine respondents, $80 \%$ stated that they were willing to pay, and some $20 \%$ stated that they were not willing.

\section{B. Econometric Analysis}

The respondent's willingness to pay (WTP) is hypothesized to be influenced by income, length of business, environmental awareness, the impact of coral reefs on the respondent's business, and education level. Regression with the ordinary least squares (OLS) method was conducted to analyze this model. In this study, testing was carried out using 3 models to determine the best model to be used for estimation. The estimation results are presented in the following Table I.

TABLE I.

REGRESSION RESULT

\begin{tabular}{|c|c|c|c|c|c|c|}
\hline \multirow[t]{2}{*}{ Variables } & \multicolumn{2}{|c|}{ Model 1} & \multicolumn{2}{|c|}{ Model 2} & \multicolumn{2}{|c|}{ Model 3} \\
\hline & Betta & t statistic & Betta & t statistic & Betta & t statistic \\
\hline Constant & -4972158 & -2.412 & -33869.31 & -2.755 & -33335.97 & -2.843 \\
\hline Income & 12958.44 & $4.464 * *$ & 13467.02 & $4.721 * * *$ & 13472.29 & $4.748 * * *$ \\
\hline Length of business & 2779.56 & $2.345 * *$ & 2648.25 & $2.250 * *$ & 2644.26 & $2.259 * *$ \\
\hline Environmental awareness & 38757.44 & 1.151 & 36836.84 & 1.096 & 41619.52 & $3.535 * * *$ \\
\hline Coral impact & 4909.63 & 0.140 & 34939.58 & 0.152 & & \\
\hline Education & 3081.11 & 0.958 & & & & \\
\hline F statistic & \multicolumn{2}{|c|}{$12.207 * * *$} & \multicolumn{2}{|c|}{$15.042 * * *$} & \multicolumn{2}{|c|}{$20.256 * * *$} \\
\hline Adj R2 & \multicolumn{2}{|c|}{0.364} & \multicolumn{2}{|c|}{0.364} & \multicolumn{2}{|c|}{0.371} \\
\hline
\end{tabular}

Source: Data analysis

** Significant at $\alpha 5 \%$

*** Significant at $\alpha 1 \%$

Table I presents the effect of the independent variables on the amount of money that respondents are willing to pay for the existence of coral reefs, or in other words, this model captures the opportunity to apply environmental service fees to tourism entrepreneurs in Gili Matra. The regression coefficient estimation shows the marginal impact of the independent variables on the amount of money that respondents are willing to pay for the PES fund.

It is found that model 3 generates the best-estimated value from the three models. Thus, that model will be used as the basis for further analysis. In model 3, the econometric analysis shows that income and environmental awareness have a significant effect on the WTP at the level of significance of $99 \%$. Meanwhile, at the $95 \%$ level of significance, the length of business influences the WTP. Business income influences the number of WTP positively and significantly. High business income respondents appear to have a more outstanding WTP rating. A rise in income by 1 million would cause the WTP to increase by Rp 13,472 ceteris paribus. Respondents with longer business lengths tend to be willing to pay more for coral reef presence. An increase in the length of business by one year would result in an increase of WTP by Rp 2,644, ceteris paribus. 
Similarly, respondents with a better degree of knowledge of the ecosystem appeared to be more likely to pay for the presence of coral reefs. An increase of environmental awareness by 1 level would raise the WTP by Rp 41,619 ceteris paribus. In the meantime, the degree of respondent's education does not impact their ability to contribute to the maintenance of coral reefs' life.

Studies on people's WTP for the existence of natural resource goods often found that a person's income greatly affects his willingness to contribute to the availability of these resources. Someone who has good financial abilities tends to be easier to contribute [17]-[23]. As stated by Turpie (2003), the willingness to pay someone for the existence of biodiversity in Africa is strongly limited by the amount of income. Likewise, what happened to PES in Sweden, people with good financial abilities tended to contribute more than those who did not. This study is also in line with Jones who examined people's willingness to pay for a good environment in Europe. In the case of Solid waste disposal, Nkansah also found that a person's income affects their WTP, which is in line with the results of this study.

Regarding the management of the coastal zone and Marine Park, Halkos and Peters found the same thing as this study, that income has a significant effect on someone's WTP for the sustainability of the ecosystem in the coastal zone. Research related to forest resources in Malaysia found the same thing as the results of this study, namely that there is an effect of a person's income on his willingness to pay for the conservation of natural resources. However, this study is not in line with the results expressed that income has no effect on a person's WTP [24].

A person's awareness of environmental benefits is also an important factor that has a strong influence on people's WTP on environmental protection. Someone who has a high awareness of environmental sustainability, usual environmentalists, tends to have a willingness to pay for the availability and preservation of natural resources [19],[22],[25]-[27]. The results of this study are in line with various research results which state that environmental awareness has a positive impact on the amount of people's willingness to pay for environmental sustainability.

\section{CONCLUSION}

This research analyzes the willingness of tourism businesses to pay for the presence of Gili Matra coral reefs. The study is seizing opportunities for the use of PES for the protection of coral reefs to synergize the tourism industry with the conservation of natural resources, in Gili Matra. This study found that the average Willingness to Pay (WTP) of tourism entrepreneurs for funding the PES program to protect coral reefs is $\mathrm{Rp} 42,200$ per month (equal to 2.99 USD). This result suggests that tourism companies are willing to pay for the environmental services that coral reef habitats produce. The amount of WTP is affected by the company's income, environmental awareness, and length of business. High-income entrepreneurs tend to have a higher WTP value. Similarly, respondents who have been in business for a longer period tend to be willing to pay higher fees. Similarly, respondents with a better degree of environmental awareness seem to be more likely to compensate for the existence of coral reefs.

\section{ACKNOWLEDGMENT}

The Author's gratitude to all parties who contributed to this research and to the University of Mataram for funding this research, with grant number 2525/UN18.L1/PP/2020.

\section{REFERENCES}

K. W. Sayogi and A. Demartoto, "PENGEMBANGAN PARIWISATA BAHARI (Studi Deskriptif Pada Pelaku Pengembangan Pariwisata Bahari Pantai Watukarung Desa Watukarung Kecamatan Pringkuku Kabupaten Pacitan)," vol. 1, no. 1 , pp. 9-17, 2018

[2] A. B. Sulistiyono, W. Mutmainnah, and M. Furusho, "4M Study to Support Indonesia's Maritime Tourism Development," TransNav, Int. J. Mar. Navig. Saf. Sea Transp., vol. 11, no. 4, pp. 723-728, 2017.

[3] S. M. Zulfitri, M. R. K. Muluk, and H. Hermawan, "Scenario Planning for the Development of Maritime Eco-tourism Object," Bisnis Birokrasi J., vol. 22, no. 2, 2016.

[4] A. A. Sinulingga et al., "The Thought of Developing Halal Maritime Tourism Destination Towards Indonesia 's Vision as a World Maritime Axis," J. PIR, vol. 2, no. 2, pp. 103-113, 2018.

[5] R. Costanza et al., "The value of the world's ecosystem services and natural capital," Nature, vol. 387, no. 6630, p. 253, 1997.

[6] D. J. Gilvear, C. J. Spray, and R. Casas-Mulet, "River rehabilitation for the delivery of multiple ecosystem services at the river network scale," J. Environ. Manage., vol. 126, no. 0, pp. 30-43, 2013.

[7] B. Fisher, R. K. Turner, and P. Morling, "Defining and classifying ecosystem services for decision making," Ecol. Econ., vol. 68, no. 3, pp. 643-653, 2009.

[8] MA, "Millenium Ecosystem Assessment 2003 ," Ecosystem and Human Well-being. A Framework for Assessment. Island Press, 2003.

[9] I. W. Suana and H. Ahyadi, "Mapping of Ecosystem Management Problems in Gili Meno, Gili Air and Gili Trawangan (Gili Matra) through Participative Approach," $J$. Coast. Dev., vol. 16, no. 1, pp. 94-101, 2013.

[10] S. Wunder, "Payment For Environmental Services: some nuts and bolts," CIFOR Occas. Pap. No. 42, 2005.

[11] S. Wunder, "The Efficiency of Payments for Environmental Services in Tropical Conservation," Conserv. Biol., vol. 21, no. 1, pp. 48-58, 2007.

[12] L. L. Bremer, K. A. Farley, and D. Lopez-Carr, "What factors influence participation in payment for ecosystem services programs? An evaluation of Ecuador's SocioPáramo program," Land use policy, vol. 36, no. 0, pp. 122-133, 2014.

[13] T. D. Allendorf, J. S. Brandt, and J. M. Yang, "Local perceptions of Tibetan village sacred forests in northwest Yunnan," Biol. Conserv., vol. 169, no. 0, pp. 303-310, 2014.

[14] P. W. Schuhmann, J. F. Casey, J. A. Horrocks, and H. A. Oxenford, "Recreational SCUBA divers' willingness to pay for marine biodiversity in Barbados," J. Environ. Manage., vol. 121 , no. 0 , pp. 29-36, 2013

[15] G. D. Israel, "Determination of sample size," 1992

[16] T. Yamane, Statistics, An Introductory Analysis, 2nd ed. New York: Harper and Row, 1967.

[17] I. Grundy et al., "SPECIAL SECTION: LAND USE OPTIONS IN DRY TROPICAL WOODLAND ECOSYSTEMS IN ZIMBABWE: Implications of co-management for benefits from natural resources for rural households in north-western Zimbabwe," Ecol. Econ., vol. 33, no. 3, pp. 369-381, 2000.

[18] S. Hökby and T. Söderqvist, "Elasticities of demand and willingness to pay for environmental services in Sweden," Environ. Resour. Econ., vol. 26, no. 3, pp. 361-383, 2003.

[19] N. Jones, C. Malesios, and I. Botetzagias, "The influence of social capital on willingness to pay for the environment among European citizens," Eur. Soc., vol. 11, no. 4, pp. 511-530, 2009.

[20] E. Nkansah, N. K. Dafor, and F. Essel-Gaisey, "Willingness to pay for improved solid waste disposal in Tema metropolis," 2015.

[21] G. Halkos and S. Matsiori, "Exploring social attitude and willingness to pay for water resources conservation," J. Behav. 
Exp. Econ., vol. 49, no. 0, pp. 54-62, 2014.

[22] H. Peters and J. P. Hawkins, "Access to marine parks: A comparative study in willingness to pay," Ocean Coast. Manag., vol. 52, no. 3-4, pp. 219-228, 2009.

[23] T. Kamri, "Willingness to pay for conservation of natural resources in the Gunung Gading National Park, Sarawak," Procedia-Social Behav. Sci., vol. 101, pp. 506-515, 2013.

[24] F. Han, Z. Yang, H. Wang, and X. Xu, "Estimating willingness to pay for environment conservation: A contingent valuation study of Kanas Nature Reserve, Xinjiang, China," Environ.
Monit. Assess., vol. 180, no. 1-4, pp. 451-459, 2011.

[25] A. Biswas and M. Roy, "A Study of Consumers' Willingness to Pay for Green Products," vol. 4, no. 3, pp. 211-215, 2016.

[26] I. Kostakis and E. Sardianou, "Which factors affect the willingness of tourists to pay for renewable energy?," Renew. Energy, vol. 38, no. 1, pp. 169-172, 2012.

[27] R. P. Vlosky, L. K. Ozanne, and R. J. Fontenot, “A conceptual model of US consumer willingness-to-pay for environmentally certified wood products," J. Consum. Mark., 1999. 